\title{
Late onset of the cryopyrin-associated periodic syndrome (CAPS) associated with low level of somatic mosaicism in six patients
}

\author{
D Rowczenio ${ }^{1 *}$, S Melo Gomes², J Arósteguii ${ }^{3}$ E Omoyinmi², E Gonzalez-Roca², A Standing ${ }^{2}$, D Eleftheriou², \\ N Klein ${ }^{2}$, P Brogan², H Lachmann' ${ }^{1}$, P Hawkins ${ }^{1}$ \\ From 8th International Congress of Familial Mediterranean Fever and Systemic Autoinflammatory Diseases \\ Dresden, Germany. 30 September - 3 October 2015
}

\section{Introduction}

CAPS is caused by mutations in the NLRP3 gene and is inherited in an autosomal dominant fashion. About $40 \%$ of children with CINCA are mutation negative by conventional Sanger sequencing, but NLRP3 somatic mosaicism can be identified by sensitive multi-parallel sequencing (MPS) in a significant proportion of such patients.

\section{Objectives}

To analyse the NLRP3 gene in six patients with typical CAPS other than onset in mid-late adult life. All patients responded to IL-1 blockade and none had a family history.

\section{Methods}

DNA was extracted from whole blood, saliva, buccal epithelial cells and from isolated monocytes, $\mathrm{T}$ and B lymphocytes and neutrophils. NLRP3 gene was analysed using Sanger sequencing and MPS.

\section{Results}

MPS detected a variable degree of somatic NLRP3 mosaicism in all patients: two carried previously described variants p.E567K and p.A352T in 5.4\% and $14.6 \%$ of alleles respectively; four had novel mutations: p.G569V, p.G564D and p.Y563C (found in two unrelated patients) in $21.1 \%$, $5 \%, 5.1 \%$ and $11.1 \%$ of alleles respectively. Analysis of purified $\mathrm{B}$ and $\mathrm{T}$ lymphocytes, neutrophils and monocytes revealed a greater proportion of mutant cells among myeloid lineage; only a small fraction of $\mathrm{T}$ lymphocytes and buccal cells carried the NLRP3 mutation. In a single adult patient who was heterozygous for germline NLRP3 substitutions p.A439V and p.S434S, the mutation was present in all lymphoid and myeloid cells. We re-analysed the NLRP3 gene in one subject who had been healthy until age 45 , but had had relentlessly worsening CAPS and steadily increasing IL-1 inhibitor requirement, using a fresh sample obtained nine years after her initial assessment; this demonstrated an increase in the frequency of the mutant allele from $5.4 \%$ to $28.6 \%$ in DNA isolated from whole blood.

\section{Conclusion}

These studies identified post-zygotic mutational events as the aetiology of late onset CAPS. All patients had excellent response to IL-1 blockade, including stabilisation of the amyloid load in the two subjects diagnosed with AA amyloidosis. AA amyloidosis is a severe complication of CAPS and hitherto has only been reported in patients with germline NLRP3 mutations. Interestingly, the population of NLRP3 mutant granulocytes and monocytes increased substantially in the single patient in whom a time course study was possible, by definition representing clonal expansion. Whilst further studies at the bone marrow level are planned, the current findings suggest that acquired NLRP3 mutations may confer affected cells with a selective advantage.

\section{Authors' details}

${ }^{1}$ National Amyloidosis Centre, UCL Medical School, London, UK. ${ }^{2}$ Institute of Child Health, UCL, London, UK. ${ }^{3}$ Hospital Clinic-IDIBAPS, Barcelona, Spain.

Published: 28 September 2015

${ }^{1}$ National Amyloidosis Centre, UCL Medical School, London, UK

Full list of author information is available at the end of the article 
doi:10.1186/1546-0096-13-S1-P37

Cite this article as: Rowczenio et al:: Late onset of the cryopyrinassociated periodic syndrome (CAPS) associated with low level of somatic mosaicism in six patients. Pediatric Rheumatology 2015

13(Suppl 1):P37.

Submit your next manuscript to BioMed Central and take full advantage of:

- Convenient online submission

- Thorough peer review

- No space constraints or color figure charges

- Immediate publication on acceptance

- Inclusion in PubMed, CAS, Scopus and Google Scholar

- Research which is freely available for redistribution

Submit your manuscript at www.biomedcentral.com/submit
C Biomed Central 